\title{
SIZING UP PHOTOVOLTAIC PUMP TO IRRIGATE SMALL CULTIVATED AREA IN NORTH SINAI
}

\author{
El-Sayed, A. S. ${ }^{1}$; Hassanain, A. A. ${ }^{2}$; Mosalhi, S. M. ${ }^{3}$
}

\begin{abstract}
In this paper, an attempt has been made to develop an irrigation water pump. The photovoltaic pump was used to watering new reclaimed region in Ber-Alabed, north Sinai, Egypt (latitude and longitude angles are $31.45^{\circ} \mathrm{N}$ and $33.0^{\circ} \mathrm{E}$, respectively) using ISWPS computer program and hourly average weather data throughout a hole year. The design criteria composed: monthly PV tilt angle, PV sizing, monthly PV usage ratio and the extra electric energy, optimum ratio between pump flow rate to pump head, and coefficient of uniformity for lateral line. It has been abstracted that, the nominal PV power was $9.08 \mathrm{~kW}$, which accept the maximum water demand in the critical month of July. The monthly $P V$ usage ratio varied between $35 \%$ and $100 \%$, and this resulted in unused PV electrical energy in water pumping of $6259 \mathrm{kWh} /$ year, which significantly reduces the fixed cost of the solar pump.
\end{abstract}

\section{INTRODUCTION}

aximizing the utilization of $\mathrm{PV}$ water pumping system
requires proper sizing for system components (Argaw, 1995).
In spite of, the photovoltaic cells contribute to $78.1 \%$ of the photovoltaic system cost (Qoaider and Steinbrecht, 2010); photovoltaic water pumps are competitive option for diesel generator pumps for agricultural extension. Many input parameters related to climate, soil, plant, and irrigation system are required for the calculation of photovoltaic pump. So, ISWPS computer program has been elaborated to be integrated solution for the calculation of photovoltaic pumping systems.

\footnotetext{
${ }^{1}$ Prof. of Agr. Eng., Suez-Canal Univ.

${ }^{2}$ Assoc. Prof. of Agr. Eng., Suez-Canal Univ.

${ }^{3}$ Agr. Eng.
} 
Cost effectiveness of PV water pumping systems requires effective utilization for PV energy and thus over sizing should be avoided (Kou et al., 1998). The required power of a photovoltaic generator to irrigate 10heactare was computed to be $8.93 \mathrm{kWp}$ in Spain (Cuadros et al., 2004). The water demand of olive orchard trees was $161 \mathrm{~m}^{3} /$ day/10-hectare at a specified head of $20 \mathrm{~m}$, and mean annual rainfall of $491 \mathrm{~mm} /$ year.

Hatem, (1990) summarized the situation of under ground water table in Egypt as given in Table (1).

Table (1): Water table in different locations of Egypt

\begin{tabular}{|l|l|}
\hline Location & Water table, $\mathbf{~ m}$ \\
\hline Sinai & $8-80$ \\
\hline East Delta & $5-133$ \\
\hline Middle Delta & $1-5$ \\
\hline West Delta & $5-115$ \\
\hline Middle Egypt & $20-100$ \\
\hline Upper Egypt & $10-120$ \\
\hline Al-Wadi El-Gadid & 50 \\
\hline
\end{tabular}

Critical month is the month in which the ratio between hydraulic and radiated solar energy is maximum (Glasnovic and Margeta, 2007).

Economic feasibility of photovoltaic technology to supply the entire energy demands to off-grid irrigated farming based community in New Kalabsha village in the Lake Nasser region, Egypt was compared with the diesel generators by Qoaider and Steinbrecht, 2010. Diesel generator cost $39 \mathrm{c} € / \mathrm{kWh}$, which compared with $13 \mathrm{c} € / \mathrm{kWh}$ in case of photovoltaic generation based on the Egypt prices in 2008 and without fuel subsidized. Furthermore, the subsidized diesel generator cost was calculated to be $12 \mathrm{c} € / \mathrm{kWh}$, which was insignificantly cheaper than that of photovoltaic generator.

The study undertaken aims to use the developed computer program "ISWPS" for sizing a photovoltaic pump sufficient to irrigate small area of olive. 


\section{MATERIALS AND METHODOLOGY}

A computer program calls ISWPS has been elaborated for the calculation of photovoltaic water pumping system. This computer program was used to find out design criteria of the photovoltaic pump. Olive orchard was selected as it is planted in widespread scale in the region. Design criteria are as follows:

1. Monthly optimum PV tilt angle.

2. Required surface area of the photovoltaic to operate the pump to deliver the water for specific time and crop type.

3. The monthly PV usage ratio (the ratio between the exactly required PV area for a specified month and maximum PV area in the critical month), and the result extra unused electrical energy in water pumping.

4. The optimum ratio between pump flow rates to pump head.

5. Coefficient of Uniformity for the irrigation network lateral lines.

\section{Parameters of ISWPS program}

Input assumption required parameters for the ISWPS computer program are presented in Table (2). Fig. (1) presents layout of the drip irrigation system, while Fig. (2) presents the lengths of the irrigation system lines.

\section{Methods}

1. Hourly average climatic conditions: the hourly average measurement data-set (five climatic parameters) for the average day of each month were obtained from Met-One station. These parameters included; solar radiation $(S R)$, ambient temperature $\left(T_{a}\right)$, wind speed $(W S)$, air relative humidity $(R H)$, and rain fall $(R F)$. A macro unit in MS-Excel was prepared for this purpose. The five climatic parameters are presented in Fig. (3) all the year round.

2. These monthly average values were used to feed the ISWPS program.

3. The PV area was calculated using the program to cover the water demand for each month. The PV area was sized till obtain the exact required PV area for each month. 
Table (2): The input parameters required for the computer program

\begin{tabular}{|l|l|}
\hline \multicolumn{1}{|c|}{ Parameter } & \multicolumn{1}{c|}{ Value } \\
\hline A: Descriptions & 5 Fadden i.e. 2.1 hectares \\
\hline Cultivated area $(145 \times 145 \mathrm{~m})$ & Sandy \\
\hline Type of soil &
\end{tabular}

B: Plant (Allen et al., 1998)

\begin{tabular}{|l|l|}
\hline Plant & Olives orchard \\
\hline Planting distances, numbers & $6 \times 6 \mathrm{~m}$, i.e. 576 plant \\
\hline Plant initial (period-coefficient) & 30 day-0.65 \\
\hline Plant development (period-coefficient) & 90 day -0.6 \\
\hline Plant mid-season (period-coefficient) & 60 day -0.7 \\
\hline Plant lat-season (period-coefficient) & 90 day -0.7 \\
\hline Plant off-season (period-coefficient) & 90 day -0.5 \\
\hline Planting date & March \\
\hline
\end{tabular}

\section{C: Irrigation network parameters}

\begin{tabular}{|l|l|}
\hline Irrigation system & Drip irrigation system \\
\hline Source of water & Ground water at $15 \mathrm{~m}$ level \\
\hline Suction pipe diameter & 3 inch $(76 \mathrm{~mm})$ \\
\hline Main line length and diameter & $108.7 \mathrm{~m}, 3$ inch $(76 \mathrm{~mm})$ \\
\hline Sub main length and diameter & $72.5 \mathrm{~m}, 2$ inch $(50.8 \mathrm{~mm})$ \\
\hline Lateral line length and diameter & $36.25 \mathrm{~m}, 1$ inch $(25.4 \mathrm{~mm})$ \\
\hline Number of sub mains & 4 \\
\hline Number of laterals for each sub main & 24 \\
\hline Emitter head & $5 \mathrm{~m}$ \\
\hline Head losses in control head & $11 \mathrm{~m}$ \\
\hline Main, sub main, and lateral type & Poly ethylene (PE) \\
\hline D: Photovoltaic pump & $11.8-90-85-50-100 \%$ \\
\hline $\begin{array}{l}\text { PV-Inverter-Motor-Pump-Matching } \\
\text { efficiencies }\end{array}$ & \\
\hline
\end{tabular}




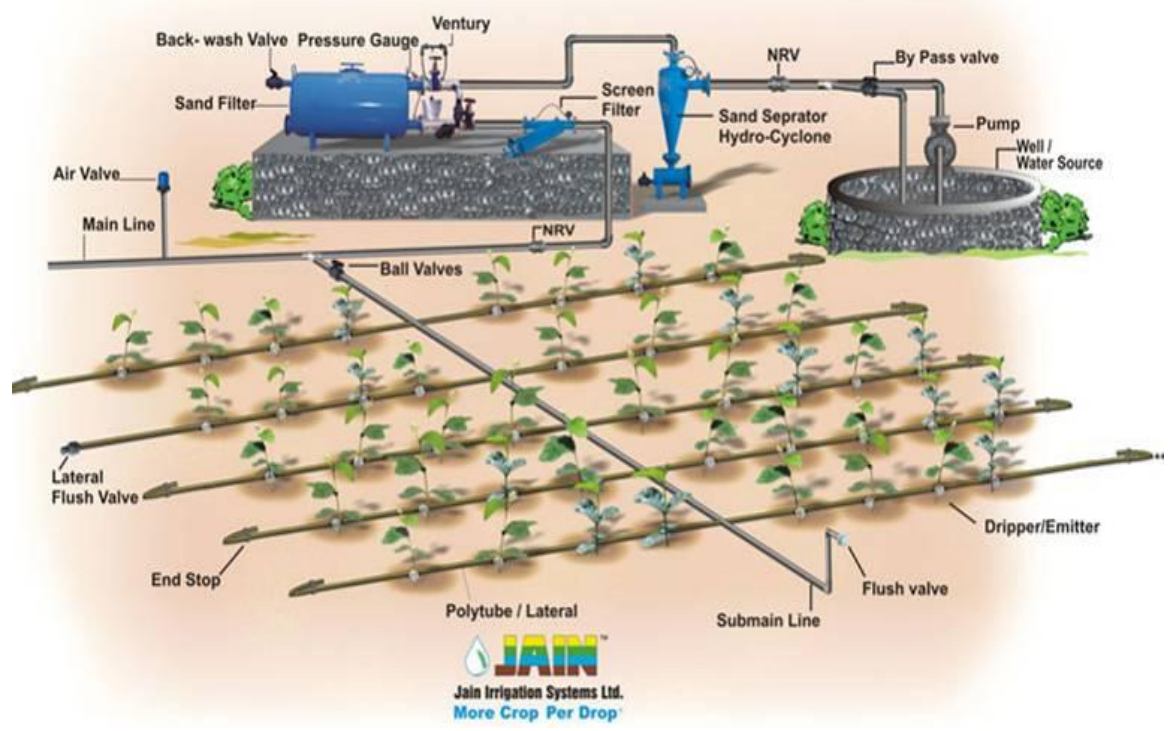

Fig. (1): Layout of the drip irrigation system

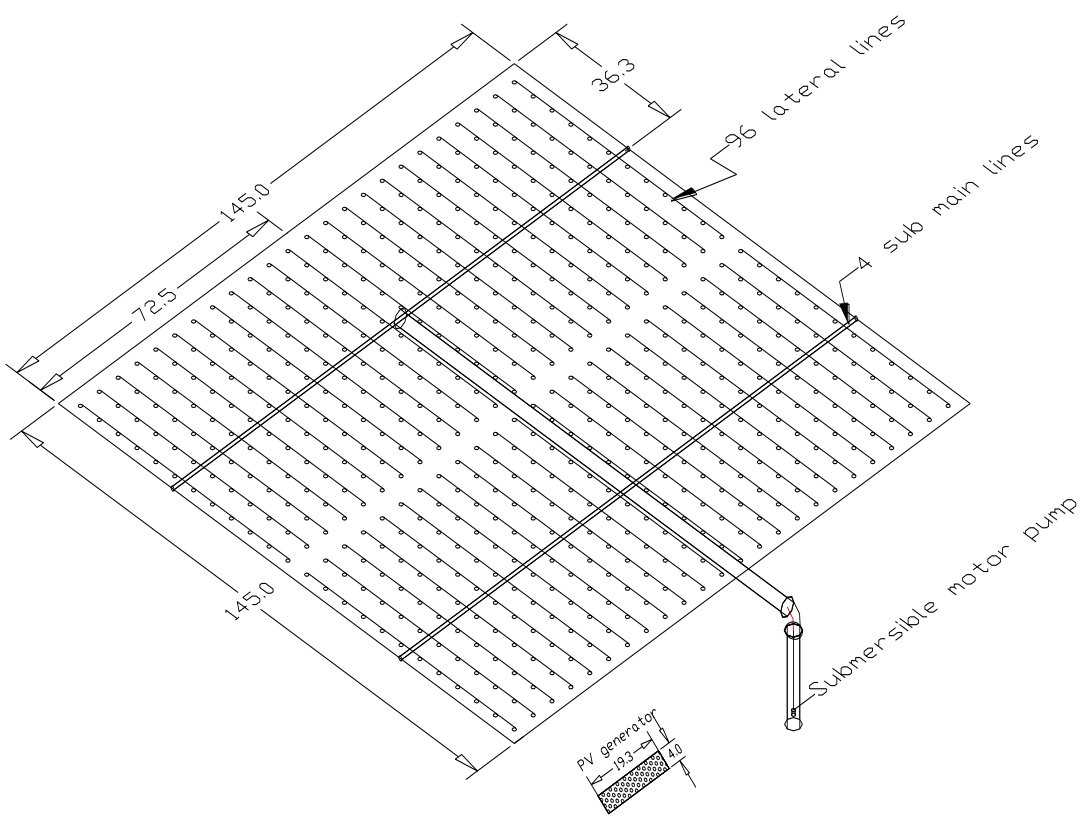

Fig. (2): Dimensions of the drip irrigation system 


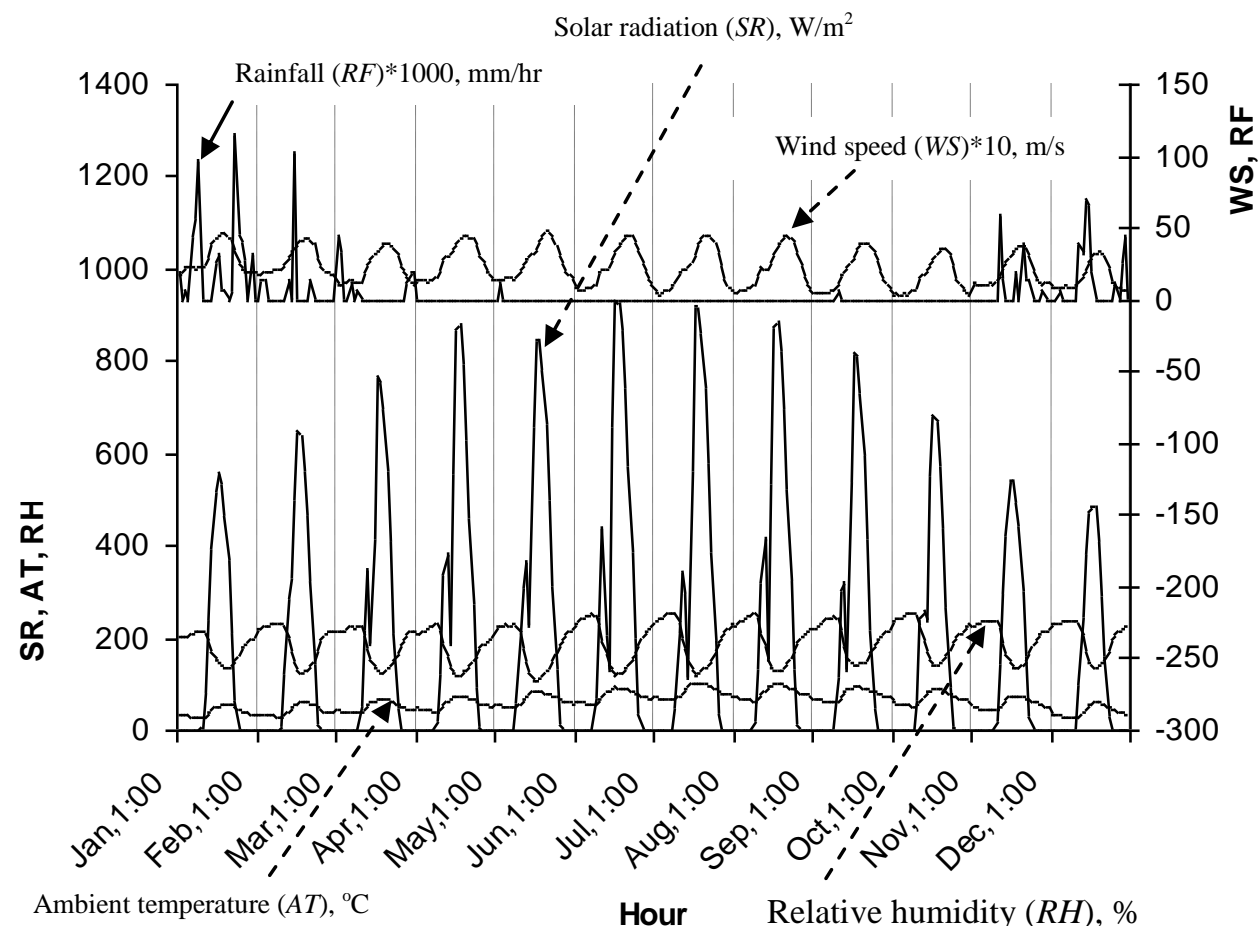

Fig. (3): Daily average of climatic conditions for North Sinai

4. The monthly average PV usage ratio and the resulted extra unused electrical energy in water pumping was calculated as follow:

- The maximum required PV area in the critical month was calculated by ISWPS program and found to be $77 \mathrm{~m}^{2}$. The monthly unused PV area in water pumping is the subtraction between the maximum PV area $\left(77 \mathrm{~m}^{2}\right)$ and the exactly required PV needed to cover the water demand in a specific month.

- The solar radiation flux incident on a tilted surface $\left(\mathrm{MJ} / \mathrm{m}^{2} /\right.$ day) for the average day of each month was computed from that measured on a horizontal surface using ISWPS program.

- Solar energy incident on the tilted unused PV area for each month was calculated from the product of the previous step and the unused $\mathrm{PV}$ area in water pumping. 
- The daily unused electrical energy $(\mathrm{kWh})$ in water pumping was calculated from the product of the previous step and both of PV efficiency and inverter efficiency.

- The monthly unused electric energy in water pumping $(\mathrm{kWh})$ was calculated from the product of the previous step and the day number of each month.

5. The ratio between pump flow rate to the head was changed till obtain the optimum ratio (the optimum ratio is the ratio which achieve the less PV area).

6. Coefficient of Uniformity for lateral line

Charts technique given in Fig. (4) by Goyal, (2007) is expressed in four steps:

Step 1: Establish along one of the lateral lines: the length of lateral line (L) of $36.25 \mathrm{~m}$ (Fig. 2), lateral operational pressure head (H) of $5 \mathrm{~m}$ (table 2), $\mathrm{L} / \mathrm{H}$ ratio of 7.25 and total discharge (Q) of 0.175 litre/sec (obtained from maximum pump discharge correspond to each lateral and for the critical month of July).

Step 2: Move vertically from $\mathrm{L} / \mathrm{H}$ (7.25) in the third quadrant to the total given discharge ( 0.175 litre/sec) in the second quadrant; then establish a horizontal line toward the first quadrant.

Step 3: Move horizontally from $\mathrm{L} / \mathrm{H}$ (third quadrant) to the percent slope in the fourth quadrant ( $1 \%$ for uniform slope); then establish a vertical line toward the first quadrant.

Step 4: The point of intersection of these two lines in the first quadrant determines the acceptability of the design.

The intersection may be located in one of the following three regions:

- Region (C) which is the desirable: A Coefficient of Uniformity (CU) over $98 \%$; equivalent to a variation in the dripper flow less than $10 \%$ or a variation in pressure less than $20 \%$.

- Region (B): is Acceptable as the Coefficient of Uniformity (CU) between 95 and $98 \%$; equivalent to a variation in the dripper flow around 10 to $20 \%$ or a variation in pressure of $20-40 \%$. 
- Region (A), Not Acceptable where the Coefficient of Uniformity less than $95 \%$; equivalent to a variation in the dripper flow over $20 \%$ or a variation in pressure greater than $40 \%$.

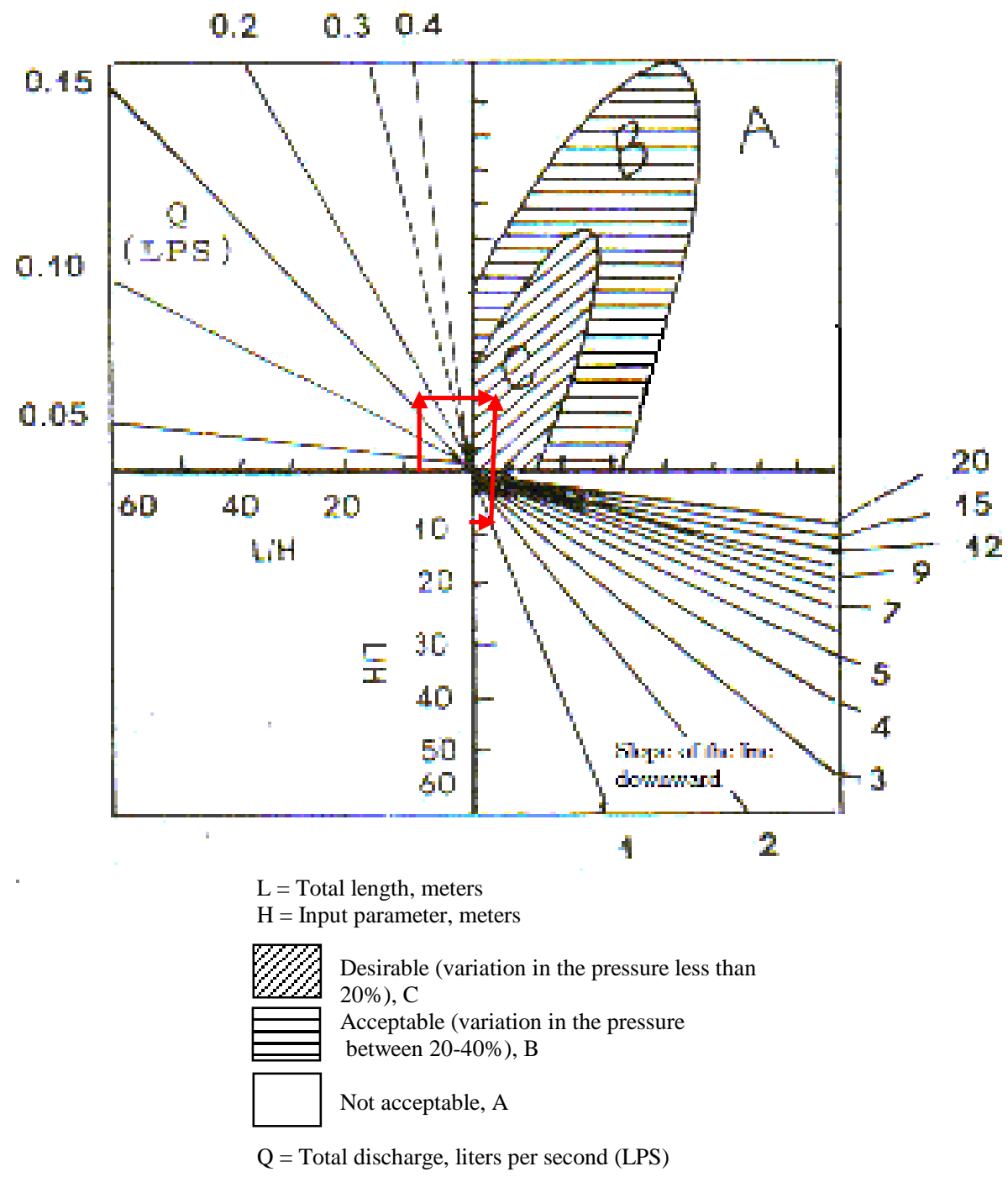

Fig. (4): Design chart for lateral line of $16 \mathrm{~mm}$ (Goyal, 2007) 


\section{RESULTS AND DISCUSSIONS}

\section{PV tilt angle}

Table (3) represents the optimum monthly tilt angles, which achieve a maximum pump flow rate. From the table, the tilt angle decreases from the beginning of the year $\left(52.4^{\circ}\right.$ for January) till the mid of the year $\left(8.4^{\circ}\right.$ for June) then increase again until the end of the year $\left(54.5^{\circ}\right.$ for December).

Table (3): Optimum tilt angle at noon for Ber-Alabed $\left(31.45^{\circ} \mathrm{N} ; 3^{\circ} \mathrm{E}\right)$

\begin{tabular}{|c|c|c|c|c|c|c|c|c|c|c|c|c|}
\hline Month & Jan. & Feb. & Mar. & Apr. & May. & Jun. & Jul. & Aug. & Sep. & Oct. & Nov. & Dec. \\
\hline $\begin{array}{c}\text { Tilt } \\
\text { angle, }\end{array}$
\end{tabular}

\section{Sizing photovoltaic surface area}

The required area of photovoltaic surface (PV) is the area required to cover the water demand in the critical month. The critical month defined as "the month in which the water demand is the highest and solar radiation is the lowest". For the undertaken design, July month is the critical month as the required PV area is $77 \mathrm{~m}^{2}$ or electrical power of 9.08 $\mathrm{kW}$ (assume PV efficiency of $11.8 \%$ at standard test conditions). Table (4) sizing the PV area and nominal PV power required to cover each month as determined by ISWPS program.

Table (4): Required PV area and power face water demands at the investigation site

\begin{tabular}{|l|c|c|c|c|c|c|c|c|c|c|c|c|}
\hline Month & Jan. & Feb. & Mar. & Apr. & May. & Jun. & Jul. & Aug. & Sep. & Oct. & Nov. & Dec. \\
\hline PV area, $\mathbf{m}^{2}$ & 31 & 34 & 27 & 33 & 44 & 50 & 77 & 63 & 68 & 57 & 45 & 30 \\
\hline $\begin{array}{l}\text { PV power, } \\
\text { kW }\end{array}$ & 3.65 & 4.01 & 3.18 & 3.89 & 5.19 & 5.9 & 9.08 & 7.43 & 8.02 & 6.72 & 5.31 & 3.54 \\
\hline
\end{tabular}

Nominal maximum power required to face water demand is $9.08 \mathrm{~kW}$ for the undertaken design. Fig. (5) presents the monthly average water quantities in terms of:

- The crop water evapo-transpiration (ETc), $\mathrm{m}^{3}$;

- The pump output in case of the monthly required PV area plus rainfall, $\left(\mathrm{m}^{3}\right)$; it was denoted as PVP-1; and

- The pump output in case of the maximum PV area $\left(77 \mathrm{~m}^{2}\right)$ plus rainfall $\left(\mathrm{m}^{3}\right)$; it was denoted as PVP-2. 


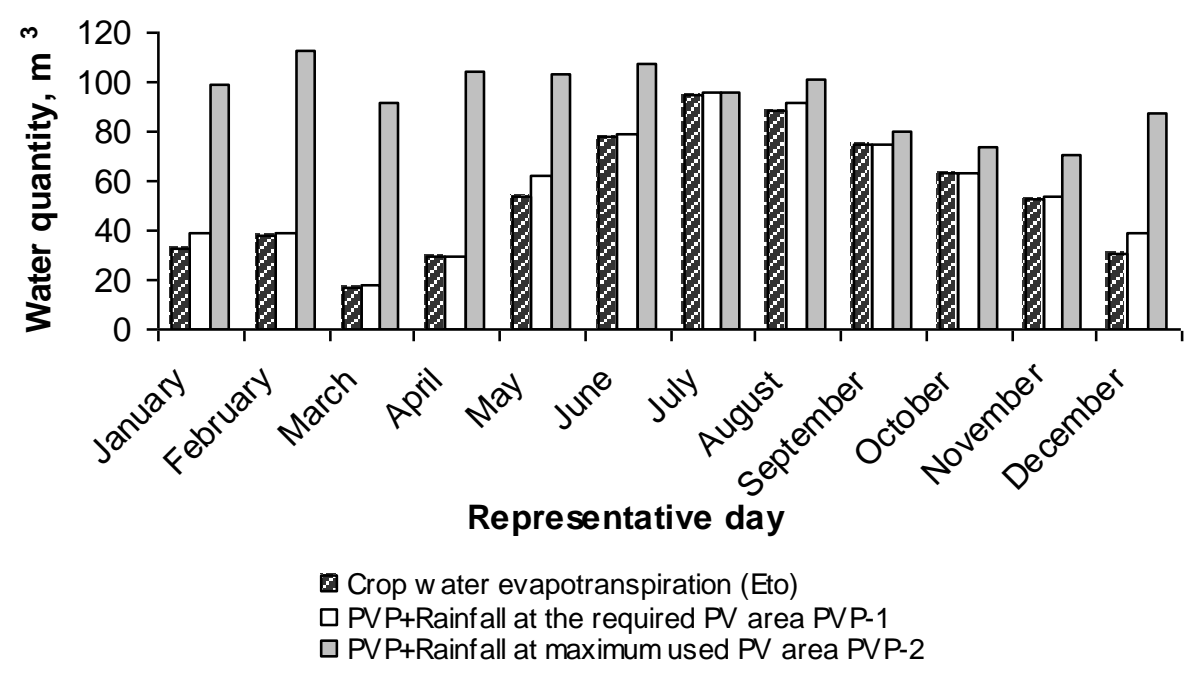

Fig. (5): Input and output water for the designed PVP

The evapo-transpiration (ETc) of olive orchard as shown in Fig. (5) varies all the year round. The nominal electric PV powers presented in Table (4) are sufficient to cover the ETc for the location and under the site climatic conditions.

\section{The PV usage ratio and the extra generated electrical energy}

Table (5) represents the monthly PV usage ratio and the resulted unused solar energy in water pumping for the study. It seems that, the monthly usage ratio varied between a minimum of $35 \%$ in March and the maximum of $100 \%$ (critical month, July). Consequently, these values resulted in unused electrical energy in water pumping of 26.8, 23.1, 27.5, $26.6,20.9,18.3,0.0,7.8,4.5,10.8,14.2$, and $24.3 \mathrm{kWh} /$ day for the months from January till December, respectively, with total energy of $6259 \mathrm{kWh} /$ year.

The following recommendations are suggested for improving solar water pumping, the unused electrical energy in water pumping may be used as follows:

- Centralized the PV generator for wide area of instance 100 Fadden. Many water pumps may be distributed throughout the cultivated area.

- Connect the PV array to the electrical grid. This bilateral technique enables the solar water pumping system to export and import required power according to the water demand. Also this will enhance the 
economical feasibility of the photovoltaic pumps. Connect PV systems to the grid allows also reducing the PV area for a lower level, and this reduces the initial cost.

- The unused PV electrical energy in water pumping as illustrated in Fig. (6) can be used in other consumption purposes such as lighting, refrigerating cell etc. An auxiliary system of diesel generator can be used in the critical months (August, September, and October).

- For the hill or mountain locations, water may be pumped and stored at high level and reused in the critical months. This may be reduced the PV generator area, consequently the initial cost.

Table (5): Monthly PV-usage-ratio and the extra unused electrical energy in water pumping processes

\begin{tabular}{|c|c|c|c|c|c|c|c|c|c|c|c|c|}
\hline Month & Jan & Feb & Mar & Apr & May & Jun & Jul & Aug & Sep & Oct & Nov & Dec \\
\hline $\begin{array}{l}\text { Average radiation, } \\
\mathrm{Wm}^{-2}\end{array}$ & 228 & 211 & 215 & 237 & 249 & 267 & 256 & 220 & 197 & 212 & 174 & 203 \\
\hline $\begin{array}{l}\text { Tilted solar energy, } \\
\mathrm{kWh} / \mathrm{m}^{2} / \text { day }\end{array}$ & 5.48 & 5.07 & 5.18 & 5.7 & 5.98 & 6.41 & 6.14 & 5.29 & 4.73 & 5.1 & 4.19 & 4.88 \\
\hline Maximum PV area, $\mathrm{m}^{2}$ & 77 & 77 & 77 & 77 & 77 & 77 & 77 & 77 & 77 & 77 & 77 & 77 \\
\hline Minimum PV area, $\mathbf{m}^{2}$ & 31 & 34 & 27 & 33 & 44 & 50 & 77 & 63 & 68 & 57 & 45 & 30 \\
\hline Unused PV area, $\mathbf{m}^{2}$ & 46 & 43 & 50 & 44 & 33 & 27 & 0.0 & 14 & 9 & 20 & 32 & 47 \\
\hline PV usage ration, \% & 40.2 & 44.1 & 35.0 & 42.8 & 57.1 & 64.9 & 100 & 81.8 & 88.3 & 74.0 & 58.4 & 38.9 \\
\hline $\begin{array}{l}\text { Daily solar energy on } \\
\text { unused PV area, } k W h\end{array}$ & 26.8 & 23.1 & 27.5 & 26.6 & 20.9 & 18.3 & 0.0 & 7.8 & 4.5 & 10.8 & 14.2 & 24.3 \\
\hline $\begin{array}{l}\text { Monthly solar energy } \\
\text { on unused PV area, } \\
\text { kWh }\end{array}$ & 831 & 672 & 853 & 800 & 650 & 551 & 0.0 & 243 & 135 & 336 & 428 & 756 \\
\hline
\end{tabular}

Average solar radiation $\left(\mathrm{Wm}^{-2}\right)$ was computed based on 24 hours

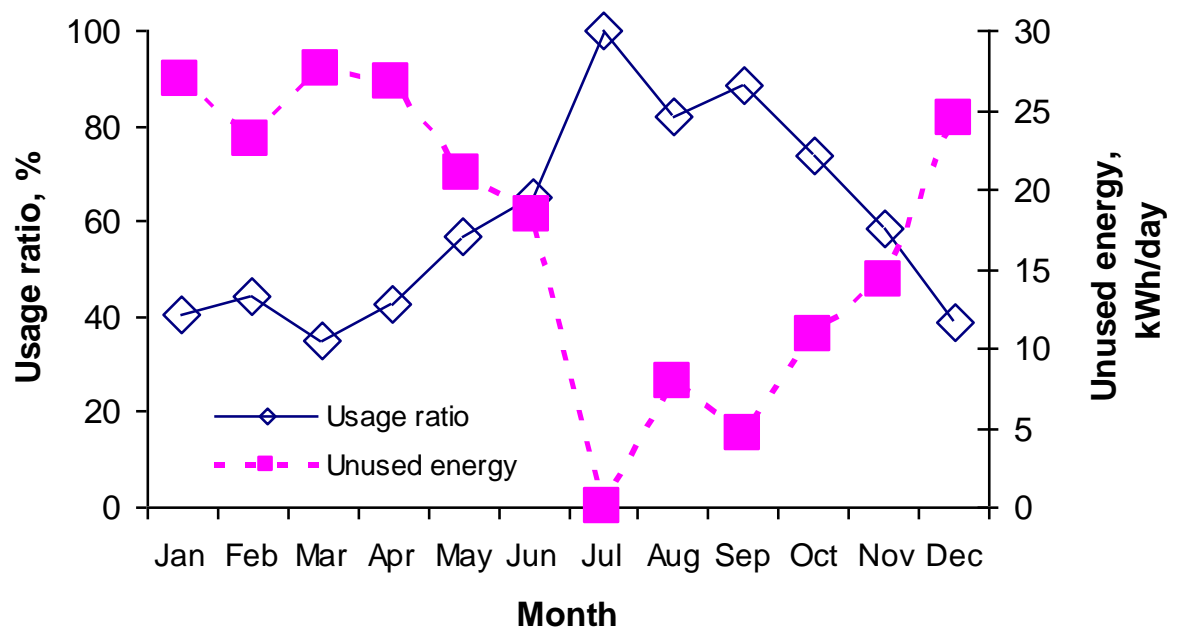

Fig. (6): Usage ratio and unused electrical energy in water pumping for the duration of one year 


\section{Optimum ratio between pump flow rates and head}

The pump flow rate and head are function of the input power to the motor-pump set. Increasing one factor will decrease the other at fixed or stable solar radiation. If a pump with a higher head was selected, reduction in the flow rate will occur, but will increase the range of solar radiation, which the pump is operating (i.e. decrease radiation threshold). Ratio between flow rate $(1 / \mathrm{min})$ and head $(\mathrm{m})$ was computed by the program to be $221 / 39$, which achieve the minimum required PV area in the critical month (July).

\section{Coefficient of Uniformity for lateral line}

The objective of this work is to introduce a comprehension design of photovoltaic pump for drip irrigation system in north Sinai region. The uniformity criterion of lateral line was tested using the charts techniques described by Goyal, 2007. Uniformity of lateral lines is discussed according to the following:

- The maximum discharge for lateral lines of $0.63 \mathrm{~m}^{3} / \mathrm{h}(0.175 \mathrm{l} / \mathrm{s})$. This discharge was the maximum predicted flow rate that was obtained from ISWPS program $\left(15.12 \mathrm{~m}^{3} / \mathrm{hr} \div 24\right.$ opened lateral).

- Length of lateral line of $36.25 \mathrm{~m}$, according to the network dimensions given in Fig. (2).

- Diameter of lateral line of 1 inch $(25.4 \mathrm{~mm})$.

- Lateral lines are on uniform slope.

- Emitter operating pressure of $5 \mathrm{~m}$.

Applying Fig. (4), the intersection is located in the first quadrant in region ' $\mathrm{C}$ ', which indicates a desirable Coefficient Uniformity of $98 \%$ and correspond variation in flow rate less than $10 \%$ and in pressure less than $20 \%$.

\section{CONCLUSION}

\section{The study conducted to the following conclusions:}

1. The maximum PV tilt angle was $54.5^{\circ}$ for December month, while the minimum tilt angle was $8.4^{\circ}$ for June; this gives an importance to design the PV carrier in this range of tilt angles.

2. The photovoltaic power required to irrigate 5 fadden of olive orchard was varied between $9.08 \mathrm{~kW}$ in July to $3.18 \mathrm{~kW}$ in March, in terms of 
the climatic conditions of north Sinai and ground water depth of 15 $\mathrm{m}$.

3. The monthly PV-usage-ratio was varied between $35 \%$ and $100 \%$, which resulted in unused PV electrical energy of $6259 \mathrm{kWh} / \mathrm{year}$ in water pumping. This amount of electrical energy enhances the economic feasibility of solar pumping.

4. Optimum ratio between pump flow rate and head was $221 \mathrm{litre} / \mathrm{min}$ to $39 \mathrm{~m}$. This ratio is the optimum to reduce the PV area in the critical month (July).

5. Coefficient of Uniformity of the lateral lines was at the desirable degree at maximum pump flow rate of $0.63 \mathrm{~m}^{3} / \mathrm{hr}$ for each opened lateral.

\section{REFERENCES}

Allen R.G.; L.S. Pereira; D. Raes and M. Smith (1998). Crop evapotranspiration-guidelines for computing crop water requirements. FAO irrigation and drainage paper 56. Report of food and agriculture organization of the United Nations, Rome.

Argaw, N. (1995). Optimal load matching in photovoltaic water pumps coupled with DC/AC inverter, International Journal of Solar Energy, 18: 41-52.

Cuadros, F.; F. López-Ródríguez; A. Arcos and J. Coello (2004). A procedure to size solar-powered irrigation (photoirrigation) schemes. Solar Energy J., 76: 465-473.

Glasovic, Z. and J. Margeta (2007). A model for optimal sizing of photovoltaic irrigation water pumping systems. Solar Energy J., Article in press.

Goyal, M. R. (2007). Management of Drip/Micro or Trickle Irrigation, University of Puerto Rico-Mayagüez Campus, ch. 13: 1-41.

Hatem, M. A. (1990). National specialized board reports. Vol. 1, Egypt, 1974-1989.

Ismail, S. M. (2002). Design and Management of Field Irrigation Systems, ( ${ }^{2}$ nd edit.). Almaarif Company, Alexandria, Egypt. (Arabic text book). 
Kou, Q.; S. Klein and W. Beckman (1998). A method for estimating the long term performance of direct-coupled PV pumping systems. Solar Energy J., 64: 33-40.

Qoaider, L. and D. Steinbrecht (2010). Photovoltaic systems: A cost competitive option to supply energy to off-grid agricultural communities in arid regions. Applied Energy J., 87: 427-435.

$$
\text { الملخص العربي }
$$

حساب القدرة لمضخة كهروشمسية اللازمة لري لرئي مساحة صغيرة بمنطقة شمال سيناء

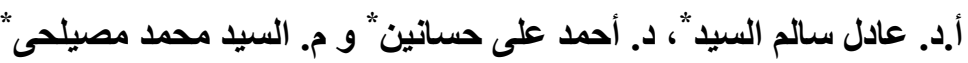

تهذف هذه الدر اسـة لتصميم مضخة كهروشمسية لري ه أفدنـة زيتون في منطقة شمال سيناء

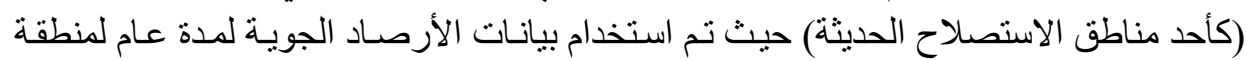

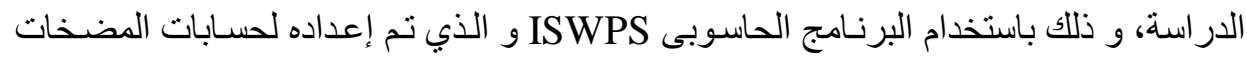
الكهروشمسية و كان النتائج المتحصل عليه من الدر اسة ما لإئي:

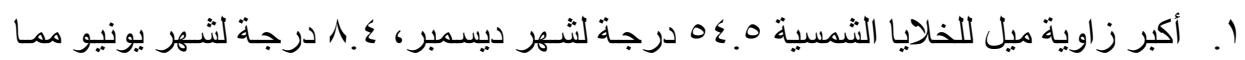

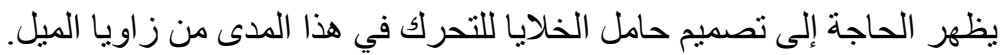

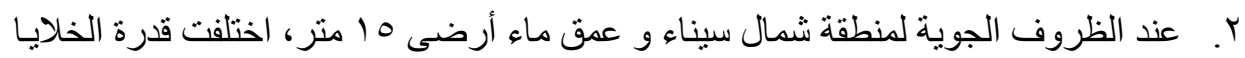

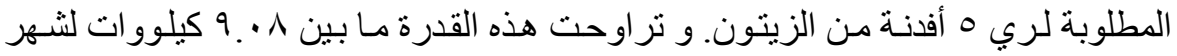

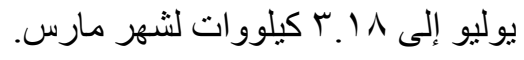

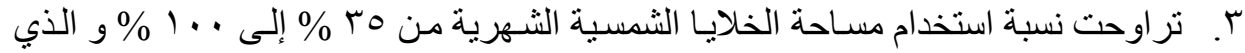

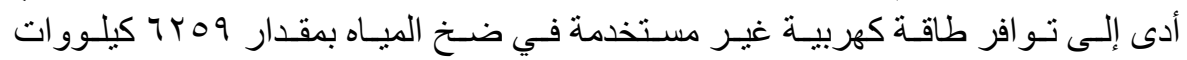

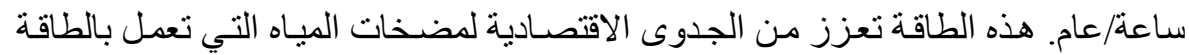
الثمسية.

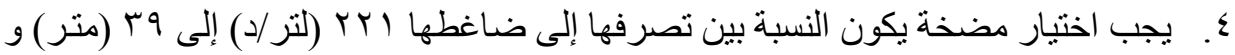

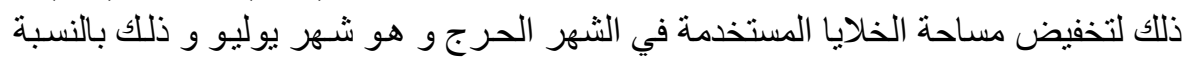
للتصميم المقترح. ๑. عند أقصى تصرف من المضخة (با7. • ) مّس لخط التنقيط، تحققت معايير الانتظامية عند الحدود المطلوبة لخطوط النقاطات.

* قسم الهندسة الزراعية ـ كلية الزراعة - جامعة قناة السويس. 